\title{
Different cytotypes in fishes of the genus Hypostomus Lcépède, 1803, (Siluriformes: Loricariidae) from Xingu river (Amazon region, Brazil)
}

\author{
S.S.R. Milhomem ${ }^{1}$, R.R. Castro ${ }^{2}$, C.Y. Nagamachi ${ }^{3,4}$, A.C.P. Souza ${ }^{5}$, \\ E. Feldberg ${ }^{4,6}$, J.C. Pieczarka ${ }^{3,4}$
}

${ }^{1}$ CAPES Masters Scholarship on Genetics and Molecular Biology, Brazil. ${ }^{2} \mathrm{CNPq}$ Scholarship on Scientific Initiation, Brazil. ${ }^{3}$ Laboratório de Citogenética - 3 Andar, Instituto de Ciências Biológicas, Universidade Federal do Pará, Av Perimetral, sn., Bairro: Guamá, Belém - Pará, 66075-900, Brasil. ${ }^{4} \mathrm{CNPq}$ Researcher, Brazil. ${ }^{5}$ CAPES Masters Scholarship on Zoology. ${ }^{6}$ Instituto Nacional de Pesquisas da Amazônia INPA, Manaus, Amazonas, Brazil.

E-mails: SSRM: susanamilhomem@yahoo.com.br, RRC: roberta.castro@yahoo. com,CYN: cleusanagamachi@pq.cnpq.br,ACPS: augustoacari@yahoo.com.br,EF: feldberg@inpa.gov.br, JCP: juliopieczarka@pq.cnpq.br, julio@ufpa.br

\begin{abstract}
We analyzed the karyotypes of three specimens of fishes of the genus $\mathrm{Hy}$ postomus Lacépède, 1803 (Loricaridae) from Xingu River (Amazon region). We used conventional staining techniques, including C-banding, Ag-NOR staining, $\mathrm{CMA}_{3}$ - and DAPI-banding. Each specimen had a different cytotype: Hypostomus sp. Xingu-1 had 2n=64 (32M/SM, 32ST/A); Hypostomus sp. Xingu-2 has 2n=66 (32M/SM, 34ST/A), and Hypostomus sp. Xingu-3 had 2n=65 (38M/SM, 26ST/A + 1 B). The three cytotypes showed similar $\mathrm{C}-, \mathrm{CMA}_{3}$ - and DAPI-banding patterns. The nucleolus organizing regions were located in the short arm of chromosome pair 25 of Hypostomus sp. Xingu-1 and pair 29 of Hypostomus sp. Xingu-2, and in the long arm of pair 30 of Hypostomus sp. Xingu-3, probably because of a pericentric inversion. A fusion/fission rearrangement explains the difference in the diploid number and number of $\mathrm{M} / \mathrm{SM}$ and ST/A chromosomes between the $2 n=64$ and $2 n=66$ cytotypes. The B chromosome most probably explains the difference between the $2 n=64$ and $2 n=65$ cytotypes. The cytotype with $2 \mathrm{n}=65$ had a significantly larger number of M/SM chromosomes, probably because of pericentric inversions. These three cytotypes may represent different species.
\end{abstract}

Key words: Siluriformes, Hypostomus, cytogenetics, heterochromatin, variability, C-banding, Ag-NOR, $\mathrm{CMA}_{3}$ and DAPI.

\section{INTRODUCTION}

The Loricariidae is one of the most diversified families within the order Siluriformes. It includes more than 600 species that may be divided into five subfamilies: Delturinae, Neoplecostominae, Hypoptopomatinae, Loricariinae and Hypostominae. These subfamilies are endemic to the Neotropical region with distributions extending from Panama to Uruguay (Isbrücker, 1980; Reis et al., 2003, 2006; Armbruster, 2004).

Using morpho-osteological analysis, Schaefer (1987) suggested that the subfamily Hypostominae is the most derived among the 
Loricariidae. The same conclusion was made by Artoni, Bertollo (1996) using cytogenetic information. The subfamily Hypostominae includes numerous species that are broadly distributed throughout almost all rivers and lakes in South America (Armbruster, 2004; Alves et al., 2006). According to Armbruster (2004), this subfamily can be divided into five tribes: Corymbophanini, Rhinelepini, Hypostomini, Pterygoplichthini and Ancistrini. The tribe Hypostomini contains a single genus, Hypostomus Lacépède, 1803, which comprises 116 species and is found in most South American waters (Isbrücker, 1980).

The subfamily Hypostominae includes the largest number of karyotyped species within the Loricariidae (Table 1). The species of the Hypostominae show significant variations in chromosome number and morphology. The diploid number $(2 \mathrm{n})$ ranges from 52 to 80 chromosomes (Artoni, Bertollo, 1996, 2001). An XX/XY sex chromosome system has been described for some species (Michele et al., 1977), whereas others have a ZZ/ZW system (Artoni, 1996). The nucleolus organizer region
(NOR) can be found as a single (Artoni, Bertollo, 1996, 2001; Artoni et al., 1998; Alves et al., 2006) or multiple pairs system (Artoni, 1996; Artoni, Bertollo, 1996; Alves et al., 2006). The composition of constitutive heterochromatin $(\mathrm{CH})$ may be species-specific in Hypostomus with some blocks rich in A-T base pairs and others rich in G-C base pairs (Artoni, Bertollo, 1999).

In the present work, we describe the karyotypes of three specimens of Hypostomus from the Xingu River in the Amazon region of Brazil.

\section{MATERIAL AND METHODS}

The specimens were collected in the Amazon region, from the Xingu River in the town of Altamira (Para, Brazil; $\left.03^{\circ} 12^{\prime} 48.0^{\prime \prime} \mathrm{S} / 52^{\circ} 12^{\prime} 41.7^{\prime} \mathrm{W}\right)$. Two females and a male were analyzed.

Because members of Hypostomus are very difficult to identify at the species level, we were unable to determine the species of our samples. Therefore, we called them

Table 1. Cytogenetic data of fishes of the genus Hypostomus in Brazil. 2n - diploid number, $\mathrm{M}$ - metacentric, SM - submetacentric, ST - subtelocentric, A - acrocentric, p - short arm, q - long arm, $\left(^{*}\right)$ - species with more than one karyotype, $\mathrm{N}$ - number of NOR bearing chromosomes.

\begin{tabular}{|c|c|c|c|c|c|c|c|c|c|}
\hline \multirow{2}{*}{ Species } & \multirow{2}{*}{ Locality } & \multirow{2}{*}{$2 n$} & \multicolumn{3}{|c|}{ Classification } & \multirow{2}{*}{$\begin{array}{c}\text { Sex } \\
\text { System }\end{array}$} & \multicolumn{2}{|c|}{ NOR } & \multirow{2}{*}{ References } \\
\hline & & & $\mathbf{M}$ & SM & ST/A & & $\mathrm{N}^{\mathbf{0}}$ & Position & \\
\hline Hypostomus sp. A & $\begin{array}{c}\text { Rincão stream, Sao } \\
\text { Paulo }\end{array}$ & 70 & 18 & 14 & 38 & - & 4 & $\mathrm{q} / \mathrm{A} ; \mathrm{p} / \mathrm{M}$ & Artoni, Bertollo, 1996 \\
\hline Hypostomus sp. B & $\begin{array}{c}\text { Mogi-Guaçu river, } \\
\text { Sao Paulo } \\
\end{array}$ & 72 & 12 & 18 & 42 & - & 2 & q/ST-A & Artoni, Bertollo, 1996 \\
\hline Hypostomus sp. B (*) & $\begin{array}{l}\text { Mogi-Guaçu river, } \\
\text { Sao Paulo }\end{array}$ & 72 & 13 & 18 & 41 & - & 2 & - & Artoni, Bertollo, 1999 \\
\hline Hypostomus sp. C & $\begin{array}{l}\text { Mogi-Guaçu river, } \\
\text { Sao Paulo }\end{array}$ & 72 & 10 & 18 & 44 & - & 3 & $\mathrm{q} / \mathrm{A}$ & Artoni, Bertollo, 1996 \\
\hline Hypostomus sp. $\mathrm{D}_{1}$ & $\begin{array}{c}\text { Mogi-Guaçu river, } \\
\text { Sao Paulo }\end{array}$ & 72 & 10 & 26 & 36 & - & 2 & $\mathrm{q} / \mathrm{ST}$ & Artoni, Bertollo, 1996 \\
\hline Hypostomus sp. $\mathrm{D}_{2}$ & $\begin{array}{l}\text { Mogi-Guaçu river, } \\
\text { Sao Paulo }\end{array}$ & 72 & 14 & 20 & 38 & - & 2 & $\mathrm{q} / \mathrm{A}$ & Artoni, Bertollo, 1996 \\
\hline Hypostomus sp. E & $\begin{array}{c}\text { Mogi-Guaçu river, } \\
\text { Sao Paulo }\end{array}$ & 80 & 8 & 16 & 56 & - & 4 & $\begin{array}{l}\mathrm{p} / \mathrm{SM} \\
\mathrm{p} / \mathrm{ST}\end{array}$ & Artoni, Bertollo, 1996 \\
\hline
\end{tabular}


Table 1. (Continuation).

\begin{tabular}{|c|c|c|c|c|c|c|c|c|c|}
\hline \multirow{2}{*}{ Species } & \multirow{2}{*}{ Locality } & \multirow{2}{*}{$2 n$} & \multicolumn{3}{|c|}{ Classification } & \multirow{2}{*}{$\begin{array}{c}\text { Sex } \\
\text { System }\end{array}$} & \multicolumn{2}{|r|}{ NOR } & \multirow{2}{*}{ References } \\
\hline & & & $\mathbf{M}$ & SM & ST/A & & $\mathbf{N}^{0}$ & Position & \\
\hline Hypostomus sp. F & \begin{tabular}{|c|} 
São Francisco river, \\
Minas Gerais \\
\end{tabular} & 76 & 10 & 16 & 50 & - & 4 & $\begin{array}{l}\mathrm{q} / \mathrm{SM} \\
\mathrm{p} / \mathrm{ST}\end{array}$ & Artoni, 1996 \\
\hline Hypostomus sp. F (*) & $\begin{array}{c}\text { São Francisco river, } \\
\text { Minas Gerais }\end{array}$ & 75 & 10 & 17 & 48 & - & - & - & Artoni. Bertollo, 1999 \\
\hline Hypostomus sp. G & $\begin{array}{l}\text { Fundo brook, } \\
\text { Araguaia river, } \\
\text { Mato Grosso } \\
\end{array}$ & 64 & 14 & 24 & 26 & ZZ/ZW & 2 & $\mathrm{p} / \mathrm{SM}$ & Artoni et al., 1998 \\
\hline $\begin{array}{l}\text { Hypostomus } \\
\text { albopunctatus }\end{array}$ & $\begin{array}{c}\text { Mogi-Guaçu river, } \\
\text { Sao Paulo }\end{array}$ & 74 & 10 & 20 & 44 & - & 4 & $\mathrm{q} / \mathrm{A} ; \mathrm{p} / \mathrm{M}$ & Artoni, Bertollo, 1996 \\
\hline $\begin{array}{l}\text { Hypostomus } \\
\text { ancistroides }\end{array}$ & - & 68 & 10 & 28 & 30 & - & - & - & Michele et al., 1977 \\
\hline $\begin{array}{l}\text { Hypostomus } \\
\text { ancistroides }\end{array}$ & \begin{tabular}{|} 
Mogi-Guaçu river, \\
Sao Paulo; \\
Monjolinho brook, \\
Sao Paulo \\
\end{tabular} & 68 & 16 & 18 & 34 & - & 6 & $\begin{array}{c}\mathrm{p} / \mathrm{M} ; \\
\mathrm{p} / \mathrm{SM} ; \mathrm{p} / \mathrm{A}\end{array}$ & Artoni, Bertollo, 1996 \\
\hline $\begin{array}{l}\text { Hypostomus } \\
\text { ancistroides }\end{array}$ & $\begin{array}{c}\text { Araquá river, Sao } \\
\text { Paulo }\end{array}$ & 68 & 18 & 10 & 40 & - & 6 & $\begin{array}{l}\mathrm{p} / \mathrm{M} \\
\mathrm{p} / \mathrm{SM} \\
\mathrm{p} / \mathrm{SM}\end{array}$ & Alves et al., 2006 \\
\hline Hypostomus affinis & $\begin{array}{c}\text { Jacuí brook, Sao } \\
\text { Paulo }\end{array}$ & 66 & 14 & 14 & 38 & - & - & - & Kavalco et al., 2005 \\
\hline $\begin{array}{l}\text { Hypostomus prope } \\
\text { auroguttatus }\end{array}$ & \begin{tabular}{|} 
Mogi-Guaçu river, \\
Sao Paulo
\end{tabular} & 76 & 8 & 30 & 38 & - & 2 & $\mathrm{q} / \mathrm{A}$ & Artoni. Bertollo, 1996 \\
\hline $\begin{array}{l}\text { Hypostomus } \\
\text { emarginatus }\end{array}$ & $\begin{array}{c}\text { Araguaia river, } \\
\text { Mato Grosso }\end{array}$ & 52 & 16 & 30 & 6 & - & 2 & $\mathrm{q} / \mathrm{M}$ & Artoni, Bertollo, 2001 \\
\hline $\begin{array}{c}\text { Hypostomus } \\
\text { goyazensis }\end{array}$ & $\begin{array}{l}\text { Vermelho river, } \\
\text { Goias }\end{array}$ & 72 & 10 & 16 & 46 & - & 2 & $\mathrm{p} / \mathrm{ST}$ & Alves et al., 2006 \\
\hline Hypostomus macrops & - & 68 & 10 & 14 & 44 & $\mathrm{XX} / \mathrm{XY}$ & - & - & Michele et al., 1977 \\
\hline $\begin{array}{c}\text { Hypostomus } \\
\text { nigromaculatus }\end{array}$ & $\begin{array}{c}\text { Mogi-Guaçu river, } \\
\text { Sao Paulo } \\
\end{array}$ & 76 & 8 & 20 & 48 & - & 2 & $\mathrm{p} / \mathrm{ST} ; \mathrm{q} / \mathrm{A}$ & Rubert et al., 2008 \\
\hline Hypostomus paulinus & - & 74 & 10 & 20 & 44 & - & - & - & Michele et al., 1977 \\
\hline $\begin{array}{l}\text { Hypostomus } \\
\text { plecostomus }\end{array}$ & - & 54 & 36 & & 18 & - & - & - & Muramoto et al., 1968 \\
\hline Hypostomus regani & $\begin{array}{l}\text { Mogi-Guaçu river, } \\
\text { Sao Paulo }\end{array}$ & 72 & 10 & 20 & 42 & - & 4 & $\mathrm{q} / \mathrm{A} ; \mathrm{p} / \mathrm{ST}$ & $\begin{array}{c}\text { Artoni, Bertollo } \\
(1996)\end{array}$ \\
\hline Hypostomus regani & $\begin{array}{c}\text { Araquá river, Sao } \\
\text { Paulo }\end{array}$ & 72 & 12 & 18 & 42 & - & 4 & $\mathrm{q} / \mathrm{A} ; \mathrm{q} / \mathrm{A}$ & Alves et al., 2006 \\
\hline $\begin{array}{c}\text { Hypostomus } \\
\text { strigaticeps }\end{array}$ & - & 74 & 8 & 4 & 62 & - & - & - & Michele et al., 1977 \\
\hline Hypostomus sp. 1 & $\begin{array}{c}\text { Quinta brook, Sao } \\
\text { Paulo }\end{array}$ & 72 & - & - & - & - & - & - & Fenerich, 1998 \\
\hline Hypostomus sp. 2 & $\begin{array}{c}\text { Alambari brook, } \\
\text { Sao Paulo }\end{array}$ & 68 & - & - & - & - & - & - & Fenerich, 1998 \\
\hline Hypostomus sp. 3 & $\begin{array}{c}\text { Paranapanema river, } \\
\text { Sao Paulo }\end{array}$ & 66 & - & - & - & - & - & - & Fenerich, 1998 \\
\hline Hypostomus sp. 4 & $\begin{array}{c}\text { Hortelã brook, Sao } \\
\text { Paulo }\end{array}$ & 76 & - & - & - & - & - & - & Fenerich, 1998 \\
\hline $\begin{array}{c}\text { Hypostomus sp. } \\
\text { Xingu-1 }\end{array}$ & Xingu river, Para & 64 & 16 & 16 & 32 & - & 2 & $\mathrm{p} / \mathrm{A}$ & Present study \\
\hline $\begin{array}{l}\text { Hypostomus sp. } \\
\text { Xingu-2 }\end{array}$ & Xingu river, Para & 66 & 18 & 14 & 34 & - & 2 & $\mathrm{p} / \mathrm{A}$ & Present study \\
\hline $\begin{array}{l}\text { Hypostomus sp. } \\
\text { Xingu-3 }\end{array}$ & Xingu river, Para & 65 & 15 & 23 & $26+1 B$ & - & 2 & $\mathrm{q} / \mathrm{A}$ & Present study \\
\hline
\end{tabular}



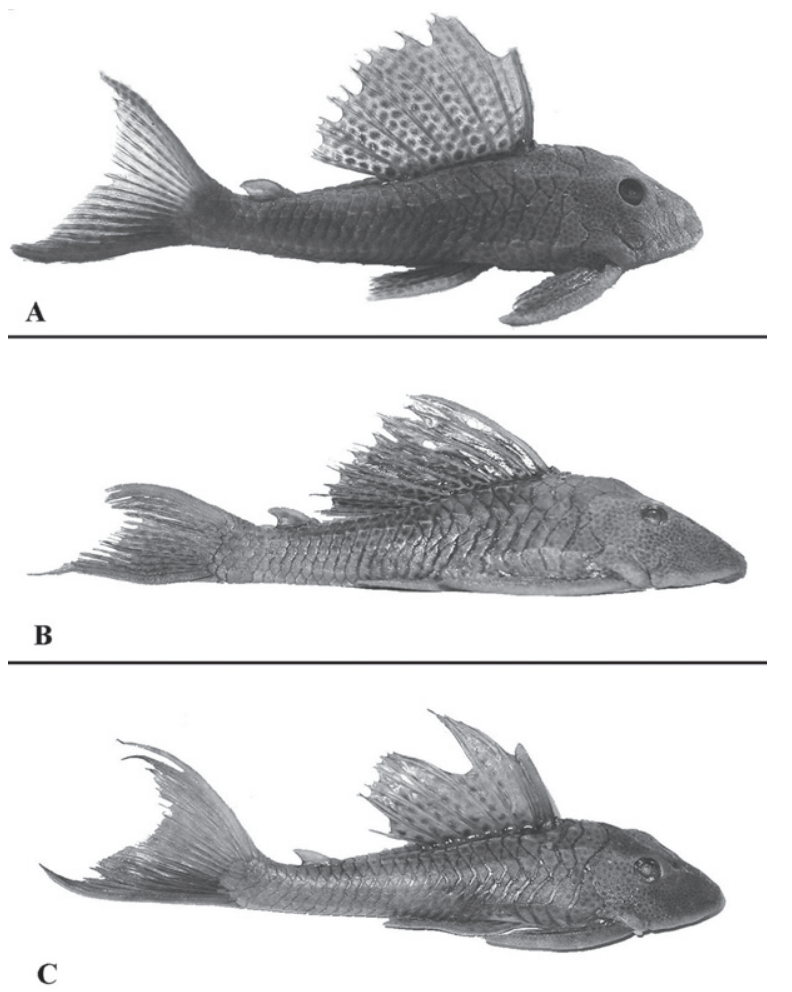

Fig. 1, a-c. a - Hypostomus sp. Xingu-1. b - Hypostomus sp. Xingu-2. c- Hypostomus sp. Xingu-3.

Hymostomus sp. Xingu-1, Hymostomus sp. Xingu-2 and Hymostomus sp. Xingu-3.

Chromosome preparation was performed as described in Bertollo et al. (1978). The chromosomes were classified as described in Guerra (1986). We used conventional staining techniques, including C-banding (Sumner, 1972), Ag-NOR staining (Howell, Black, 1980), and the fluorochromes chromomycin $\mathrm{A}_{3}\left(\mathrm{CMA}_{3}\right)$ (Schweizer, 1980) and 4'6'diamidino-2-phenylindole (DAPI) (Pieczarka et al., 2006).

The fish specimens studied were vouchered at the Museu Paraense Emilio Goeldi (MPEG) under the following numbers: Hymostomus sp. Xingu-1, MPEG 13431; Hymostomus sp.
Xingu-2, MPEG 13430; and Hymostomus sp. Xingu-3, MPEG 13429.

\section{RESULTS}

Hymostomus sp. Xingu-1, a female (Fig. 1, a), shows $2 \mathrm{n}=64$ and a karyotype formula (KF) with 32M/SM+32ST/A (Fig. 2, a). Hymostomus sp. Xingu-2, a male (Fig. 1, b), shows $2 \mathrm{n}=66$ and $\mathrm{KF}$ with $32 \mathrm{M} / \mathrm{SM}+34 \mathrm{ST} / \mathrm{A}$ (Fig. 3, a). Hymostomus sp. Xingu-3, a female (Fig. 1, c), shows $2 \mathrm{n}=65, \mathrm{KF}$ with $38 \mathrm{M} /$ $\mathrm{SM}+26 \mathrm{ST} / \mathrm{A}+1 \mathrm{~B}$ microchromosome (Fig. 4, a).

Hymostomus sp. Xingu-1 has blocks of $\mathrm{CH}$ in the distal region of both arms of metacentric pair 14, in the proximal region of the long arm and the distal region of the short arm of submetacentric pair 6 , and at the distal region of the long arm of pair 25 (Fig. 2, B). Hymostomus sp. Xingu-2 has evident heterochromatic blocks found in the distal regions of both arms of metacentric pair 13 and in the distal region of the long arm of pair 29. There is a size heteromorphism of the $\mathrm{CH}$ block in the proximal region of the long arm of pair 4 (Fig. 3, B). In Hymostomus sp. Xingu-3 chromosome pair 9 is heteromorphic: one of the homologues is metacentric and the other is submetacentric, due to a heteromorphism of the heterochromatin in the proximal region of the long arm: there is an interstitial heterochromatic block in only one of the homologues (Fig. 4, b). Chromosome pair 5 has small blocks of heterochromatin in the distal regions of both arms (Fig. 4, b).

In Hymostomus sp. Xingu-1, the NOR is of the simple type, and it is located on the distal short arm of pair 25 (Fig. 5, a). Heteromorphism in the NOR size was found, and the NOR is C-band negative. In Hymostomus sp. Xingu-2, the NOR is present in the short arm of pair 29 (Fig. 5, b). In Hymostomus sp. Xingu-3 the NOR is found 


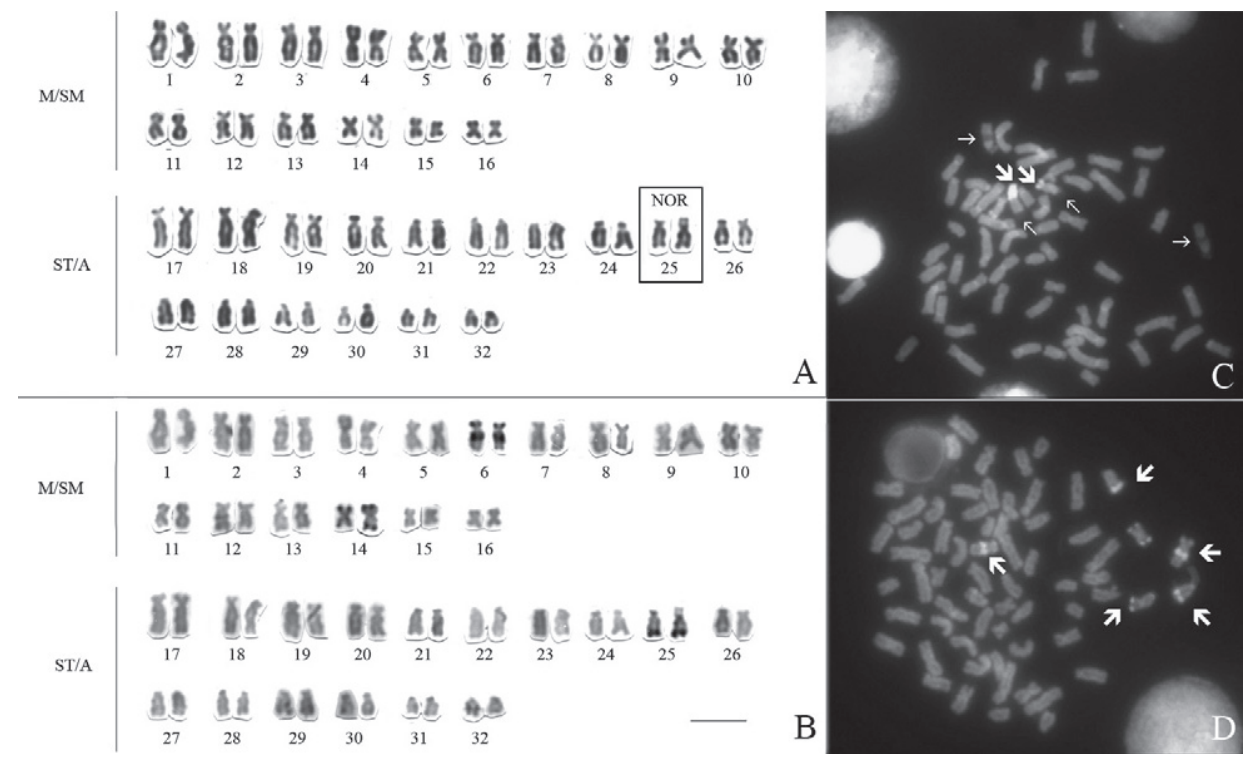

Fig. 2, a-d. Karyotype of Hypostomus sp. Xingu-1. a - Giemsa staining, showing the NOR-bearing pair. b - Cbanded karyotype. $\mathbf{c}$ - metaphase spread stained with $\mathrm{CMA}_{3}$ (larger arrows show the NOR region, smaller arrows show the $\mathrm{CMA}_{3}$-quenched regions). d - DAPI-banding (arrows show the positive C-banded regions that are A-T rich). Bar $=10 \mu \mathrm{m}$.

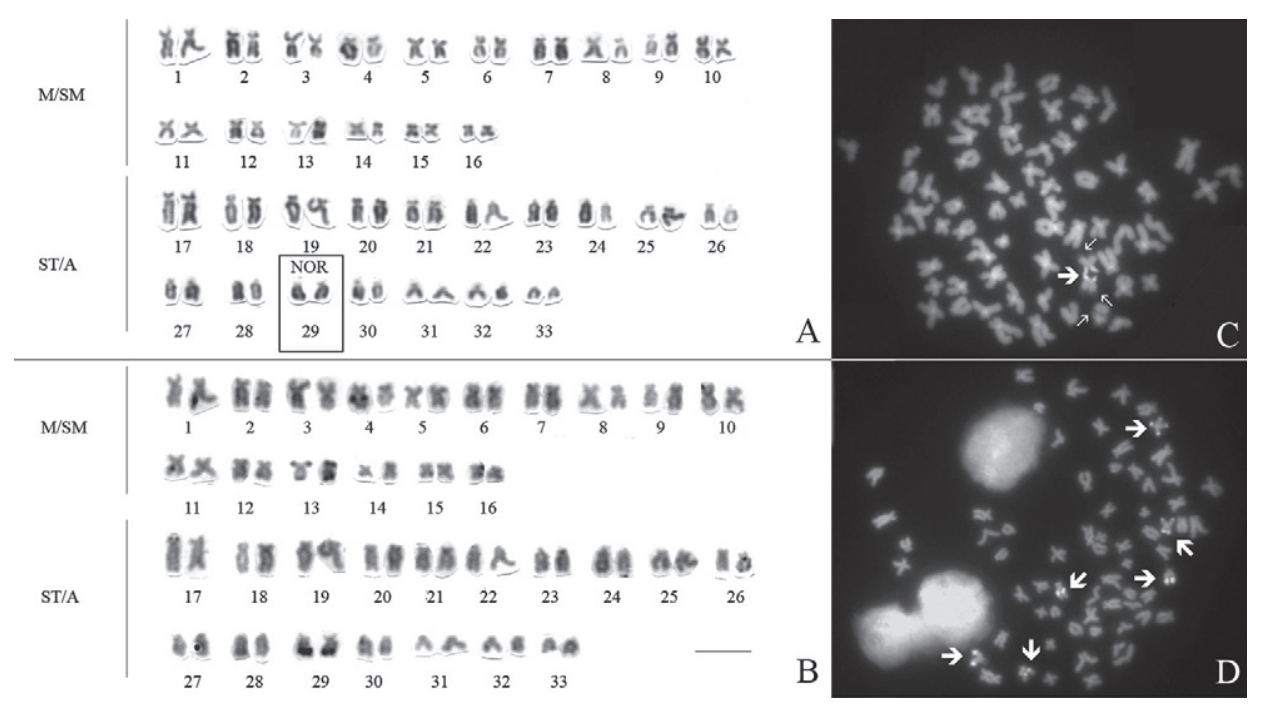

Fig. 3, a-d. Karyotype of Hypostomus sp. Xingu-2. a - Giemsa staining, showing the NOR-bearing pair. b - Cbanded karyotype. $\mathbf{c}$ - metaphase spread stained with $\mathrm{CMA}_{3}$ (larger arrows show the NOR region, smaller arrows show the $\mathrm{CMA}_{3}$-quenched regions). d - DAPI-banding (arrows show the positive C-banded regions that are A-T rich). Bar $=10 \mu \mathrm{m}$. 


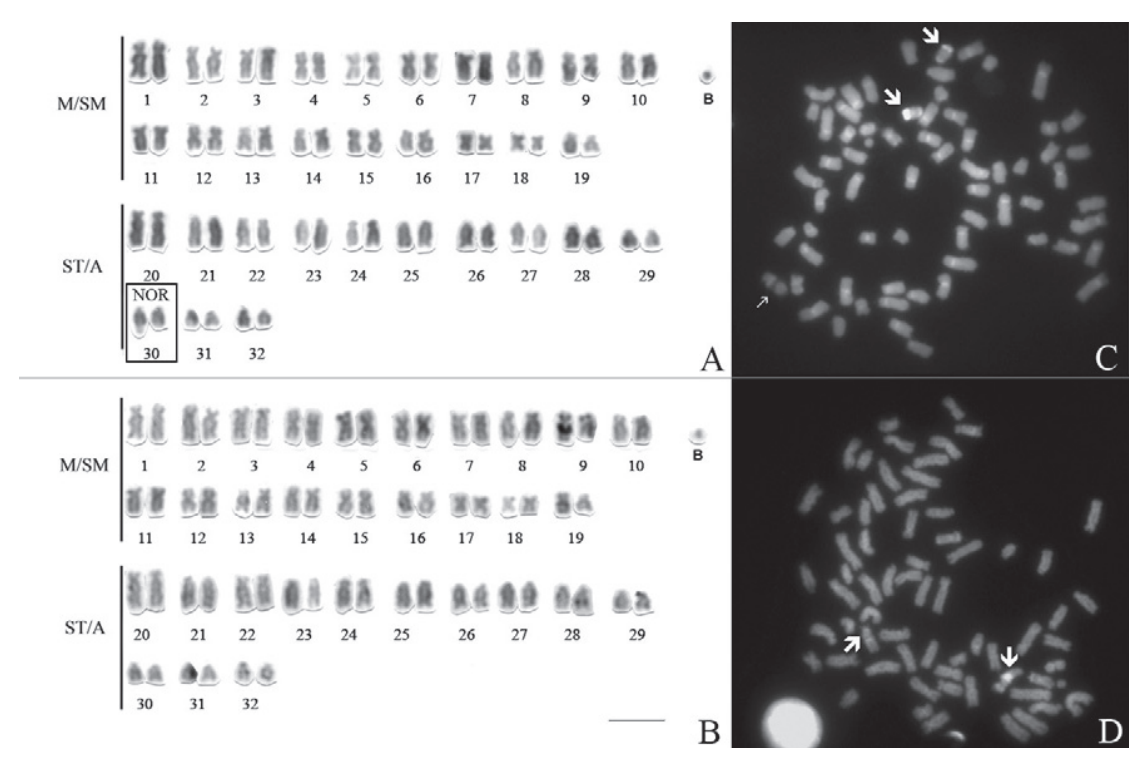

Fig. 4, a-d. Karyotype of Hypostomus sp. Xingu-3. a - Giemsa staining, showing the NOR-bearing pair (B represents the minichromosome). $\mathbf{b}$ - C-banded karyotype. $\mathbf{c}$ - metaphase spread stained with $\mathrm{CMA}_{3}$ (larger arrows show the NOR region, smaller arrows show the $\mathrm{CMA}_{3}$-quenched regions). $\mathbf{d}$ - DAPI-banding (arrows show the positive C-banded regions that are A-T rich). Bar $=10 \mu \mathrm{m}$.

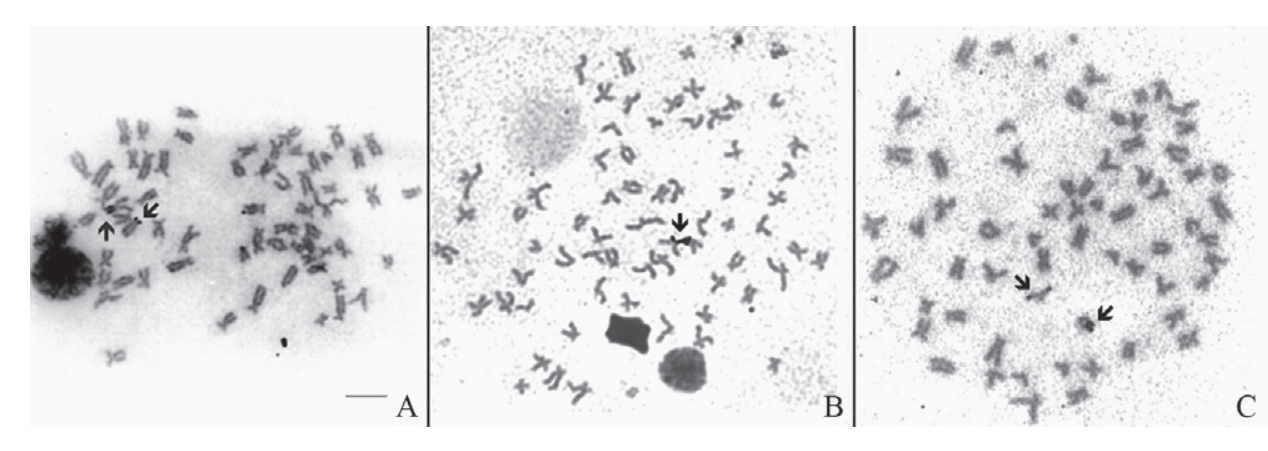

Fig. 5, a-c. Metaphases submitted to Ag-NOR technique. The arrows show the NOR-bearing chromosomes. a - Hypostomus sp. Xingu-1. b - Hypostomus sp. Xingu-2. c - Hypostomus sp. Xingu-3. Bar $=10 \mu \mathrm{m}$.

at the distal region of the long arm of pair 30 and shows size heteromorphism (Fig. 5, c).

The heterochromatic blocks of pairs 6,14 and 25 produce bright DAPI fluorescence (Fig. 2, d) in Hymostomus sp. Xingu-1, whereas the heterochromatic blocks of pairs 14 and 25 have quenched $\mathrm{CMA}_{3}$ fluorescence. As they also are DAPI bright, these regions are likely to be rich in A-T base pairs. In Hymostomus sp. Xingu-2 the heterochromatic blocks of pairs 4, 13 and 29 are DAPI-bright (Fig. 3, d). $\mathrm{CMA}_{3}$ staining is bright at the centromeres and at the NOR (Fig. 3, c), while the $\mathrm{CH}$ blocks of pairs 4 and 29 are $\mathrm{CMA}_{3}$-quenched (Fig. 3, c). Hymostomus sp. Xingu-3 has DAPI staining bright in the heterochromatin blocks of pairs 


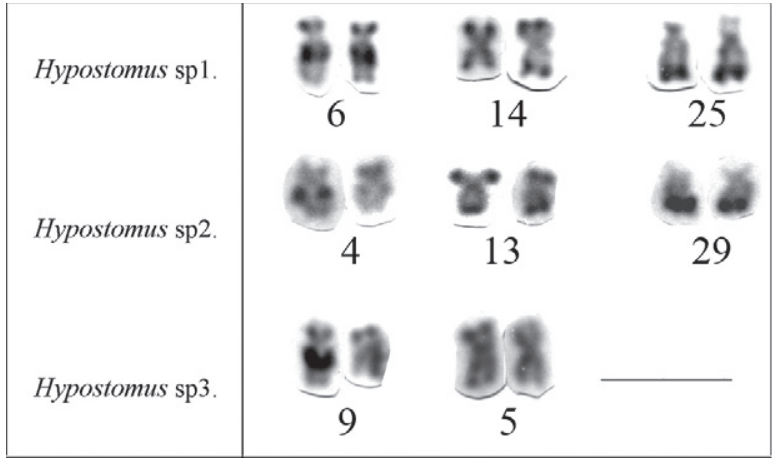

Fig. 6. Probable homologies among the specimens studied herein, as suggested by C-banding. Bar $=10$ $\mu \mathrm{m}$.

5 and 9 (Fig. 4, d). $\mathrm{CMA}_{3}$ is bright in most of the centromeres and in the NOR (Fig. 4, c), whereas the above mentioned heterochromatic block in pair 9 is $\mathrm{CMA}_{3}$-quenched (Fig. 4, c). The additional small chromosome (a " $\mathrm{B}$ " or supernumerary chromosome) is neither heterochromatic nor bright with DAPI or $\mathrm{CMA}_{3}$ staining.

\section{DisCUSSION}

A comparative analysis of the three karyotypes suggests that a fusion/fission-type rearrangement could explain the differences in the $2 n$ and in the number of M/SM and ST/A chromosomes between the cytotypes with $2 n=64$ and $2 n=66$. The presence of a $B$ chromosome explains the difference in the $2 n$ of the cytotypes with $2 n=65$ and $2 n=64$. In addition, the cytotype with $2 \mathrm{n}=65$ has more $\mathrm{M} / \mathrm{SM}$ chromosomes than the other cytotypes, probably because of pericentric inversions.

When comparing our results with prior descriptions in the literature, we have found that Hymostomus sp. Xingu-1 $\quad(2 \mathrm{n}=64$; $32 \mathrm{M} / \mathrm{SM}+32 \mathrm{ST} / \mathrm{A}$ ) has the same diploid number as Hymostomus sp. G $(2 \mathrm{n}=64$; 14M+24SM+26ST/A, Artoni et al., 1998), while Hymostomus sp. Xingu-2 $(2 \mathrm{n}=66 ; 32 \mathrm{M} /$
$\mathrm{SM}+34 \mathrm{ST} /$ ) has the same diploid number as $H$. affinis Steindachner, $1877(2 \mathrm{n}=66$; $14 \mathrm{M}+14 \mathrm{SM}+38 \mathrm{ST} / \mathrm{A}$, Kavalco et al., 2005). However, the karyotypic formulae differ in both cases, probably because of pericentric inversions, which can change chromosome morphology without changing the diploid number.

The third cytotype, Hymostomus sp. Xingu-3 $(2 \mathrm{n}=65 ; 38 \mathrm{M} / \mathrm{SM}+26 \mathrm{ST} / \mathrm{A}+1 \mathrm{~B})$ has a karyotype similar to that of Hymostomus sp. $\mathrm{G}$, described above. However, Hymostomus sp. Xingu-3 differs from Hymostomus sp. G in the heteromorphism of pair 9 and the presence of a B chromosome. Notably, this is the first report of a $\mathrm{B}$ chromosome in Hypostomus. This comparison suggests that Hymostomus sp. Xingu-3 is more similar to Hymostomus sp. G from the Araguaia River (which is linked to the Amazon basin), than to the other two cytotypes obtained from the Xingu River.

All the three specimens have NORs of a simple type located respectively on the short arms of pairs 25 and 29, and the long arm of pair 30. The difference in the NOR position in Hymostomus sp. Xingu-3 can be explained by a pericentric inversion. In fishes, NORs are often found on a single pair of chromosomes, as seen in Hypostomus (Artoni, Bertollo 1996, 2001; Artoni et al., 1998, Alves et al., 2006), although there are many inter- and intraspecific deviations from this trend (Oliveira, 1987; Andreata, 1991; Fenocchio, 1993; Artoni, 1996; Souza, 2003). Artoni (1996) claimed that most of the Hypostominae species with a single pair of NORs have heteromorphism in NOR size. This is consistent with the pattern we found in Hymostomus sp. Xingu-1 and Hymostomus sp. Xingu-3 (Fig. 5).

The NORs showed bright $\mathrm{CMA}_{3}$ banding, indicating that these sequences are G-C rich. This fluorochrome stains regions independently of the transcriptional activity in the previous interphase (Howell, 1977; Almeida-Toledo, 1998). 
Hypostomus has relatively little constitutive heterochromatin (Artoni, 1996). The cytotypes studied by us have very similar patterns of heterochromatin distribution, with only few chromosome pairs showing small heterochromatic blocks. It is possible to compare the homologies among the pairs based on their heterochromatin patterns (Fig. 6). Our $\mathrm{CMA}_{3}$ and DAPI staining results suggest that the three cytotypes have a heterogeneous composition of constitutive heterochromatin, with some blocks rich in A-T base pairs (DAPI bright) and other rich in G-C base pairs $\left(\mathrm{CMA}_{3}\right.$ bright). The same result was found in some species of Hypostomus by Artoni and Bertollo (1999). However, these results differ from that obtained by Kavalco et al. (2005), who demonstrated that $H$. affinis has its $\mathrm{CH}$ exclusively rich in GC pairs.

According to Camacho et al. (2000) the B chromosomes are typically heterochromatic. Andreata et al (1993) described two large heterochromatic B chromosomes in Microlepidogaster leucofrenatus (Miranda Ribeiro, 1908) (Siluriformes: Loricariidae). In our study the B-chromosome was neither heterochromatic nor especially rich in AT or GC-bp. More detailed molecular studies may help to understand its nature.

Artoni and Bertollo(2001) proposed that the karyotypes with $2 \mathrm{n}=54$ should be an ancestral condition in Hypostomus karyotypes, since this diploid number is found in different genera and even families. As a consequence, centric fissions must be important rearrangements for the evolution of karyotypes of Hypostomus, in which the diploid numbers range from $2 n=52$ to $2 n=80$ (Table 1 ). Also, the number of ST/A chromosomes increases in karyotypes with higher diploid numbers, with a consequent reduction in the number of $\mathrm{M} / \mathrm{SM}$ chromosomes. Kavalco et al. (2005) suggest that Robertsonian rearrangements, as well as pericentric inversions, were the main changes related with the karyotypic diversification of the Hypostominae. Our data are in agreement with this suggestion, since the differences among the three karyotypes studied can be a consequence of these rearrangements.

Despite the differences in diploid numbers and karyotypic formulae, the three cytotypes share similar patterns of heterochromatin distribution and the presence of a single NOR. These results suggest that: a) the three specimens could be members of a single species that maintains the observed chromosome differences as polymorphisms; b) the population could be undergoing a chromosome-based speciation event through which individuals are diverging from a common ancestor; or c) the specimens may represent members of different species that arose from a common ancestor. Additional studies will be required to distinguish among these possibilities, but at the moment the option "c" seems to be the most reasonable. The lack of cytogenetic information and the lack of knowledge of most of the species morphology (see Table 1, where many Hypostomus are "sp.") turns the Hypostomus genus one of the most interesting for any kind of study. New information is always helpful, like that described here.

\section{ACKNOWLEDGEMENTS}

This research was supported by $\mathrm{CNPq}$, CAPES and UFPa. The sample collection was authorized by IBAMA (Instituto Brasileiro do Meio Ambiente) permission 020/2005 (IBAMA registration: 207419).

\section{REFERENCES}

Almeida-Toledo L. F. 1998. Cytogentic markers in neotropical freshwater fishes, (pp. 583-588) // Malabarba L.R., Reis R.E., Vari R.P., Lucena Z.M.S., Lucena C.A.S. (Eds). Phylogeny and Classification 
of Neotropical Fishes. Porto Alegre. 540 p.

Alves L.A., Oliveira C., Nirchio M., Granado A., Foresti F. 2006. Karyotypic relationships among the tribes of Hypostominae (Siluriformes: Loricariidae) with description of XO sex chromosome system in a Neotropical fish species // Genetica. 128: 1-9.

Andreata A.A. 1991. Estudos citogenéticos na subfamília Hypoptopomatinae (Pisces, Siluriformes, Loricariidae). Unpublished Mastership Dissertation. São Paulo, Universidade de São Paulo. 171 p.

Andreata A.A., Almeida-Toledo L.F, Oliveira C., Almeida-Toledo Filho S. 1993. Chromosome studies in Hypoptopomatinae (Pisces, Siluriformes, Loricariidae) // Cytogenet. Cell Genet. 63: 215220.

Armbruster J.W. 2004. Phylogenetic relationships of the suckermouth armoured catfishes (Loricariidae) with emphasis on the Hypostominae and the Ancistrinae // Zool. J. Linnean Soc. 141: 1-80.

Artoni R.F. 1996. Estudos Citogenéticos na Família Loricariidae, com ênfase no gênero Hypostomus Lacépède(1803)(Pisces, Siluriformes). Unpublished Mastership Dissertation, São Carlos, SP. 162 p.

Artoni R.F., Bertollo L.A.C. 1996. Cytogenetic studies on Hypostominae (Pisces, Siluriformes, Loricariidae): Considerations on karyotype evolution in the genus Hypostomus // Caryologia. 49: 81-90.

Artoni R.F., Bertollo L.A.C. 1999. Nature and distribution of constitutive heterochromatin in fishes, genus Hypostomus (Loricariidae) // Genetica. 106: 209-214.

Artoni R.F., Bertollo L.A.C. 2001. Trends in the karyotype evolution of Loricariidae Fish (Siluriformes) // Hereditas. 134: 201-210.

Artoni R.F., Vênere P.C., Bertollo L.A.C. 1998. A heteromorphic ZZ/ZW sex chromosome system in fish, genus Hypostomus (Loricariidae) // Cytologia. 63: 421-425.

Bertollo L.A.C., Takashi C.S., Moreira-Filho O. 1978. Cytotaxonomic considerations on Hoplias lacerdae (Pisces, Erythrinidae) // Brazilian J. Genet. 1: $103-120$.

Camacho J.P.M., Sharbel T.F., Beukeboom L.W. 2000. B-chromosome evolution. Phil. Trans. Soc. Lond. B. 355: 163-178.

Fenerich P.C. 1998. Estudo de conteúdo de DNA nuclear em células de peixes da ordem Siluriformes (Pisces, Ostariophysi), da região de Botucatu, SP. MSc Thesis, Universidade Estadual Paulista. 127 p.

Fenocchio A.S. 1993. Cromossomos supranumerários no gênero Rhamdia (Pisces). Caracterização cromossômica e considerações sobre evolução cariotípica em Siluroidei. Unpublished Ph.D Thesis,
Universidade de São Paulo,Ribeirão Preto, SP. $122 \mathrm{p}$.

Guerra M.S. 1986. Reviewing the chromosome nomenclature of Levan et al. // Rev. Brazilian Genet. 4: 741-743.

Howell W.M. 1977. Visualization of ribosomal gene activity: Silver stains proteins associated with rRNA transcribed from oocyte chromosomes // Chromosoma. 62: 361-367.

Howell W.M., Black D.A. 1980. Controlled silverstaining of nucleolus organizer regions with a protective colloidal developer: a 1-step method // Experientia. 36: 1014-1015.

Isbrücker I.J.H. 1980. Classification and catalogue of the mailed Loricariidae (Pisces, Siluriformes). Verslagen en Technische Gegevens, Universiteit van Armsterdam, 22. $188 \mathrm{p}$.

Kavalco K.F., Pazza R., Bertollo L.A.C., MoreiraFilho O. 2005. Karyotypic diversity and evolution of Loricariidae (Pisces, Siluriformes) // Heredity. 94: 180-186.

Michele J.L., Takahashi C.S., Ferrari I. 1977. Karyotypic study of some species of the family Loricariidae // Cytologia. 42: 539-546.

Muramoto I., Ohno S., Atkin N.B. 1968. On the diploid state of the fish order Ostariophysi // Chromosoma. 24: 59-66.

Oliveira C. 1987. Estudos citogenéticos no gênero Corydoras (Pisces, Siluriformes, Callichthyidae). Unpublished Mastership Dissertation, Universidade de São Paulo, São Paulo, SP. 154 p.

Pieczarka J.C., Nagamachi C.Y., Souza A.C.P., Milhomem S.S.R., Castro R.R., Nascimento A.L. 2006. An adaptation to DAPI-banding to fishes chromosomes // Caryologia. 59: 43-46.

Reis R.E., Kullander S.O., Ferraris Jr. C.J. 2003. Check List of the Freshwater Fishes of South America. Edipucrs, Porto Alegre. 729 p.

Reis R.E., Pereira E.L., Armbruster J.W. 2006. Delturinae, a new loricariid catfish subfamily (Teleostei, Siluriformes), with revisions of Delturus and Hemipsilichthys // Zool. J. Linnean Soc. 147: 277-299.

Rubert M. Zawadzki C.H., Giuliano-Caetano L. 2008. Cytogenetic characterization of Hypostomus nigromaculatus (Siluriformes: Loricariidae) // Neotropical Ichthyol. 6: 93-100.

Schaefer S.A. 1987. Osteology of Hypostomus plecostomus (Linnaeus), with a phylogenetic analysis of the loricariid subfamilies (Pisces Siluroidei) //Natur. Hist. Mus. Los Angeles County, Contrib. Sci. 394: 1-31.

Schweizer D. 1980. Simultaneous fluorescent staining of $\mathrm{R}$ bands and specific heterochromatic regions 
(DA/DAPI Bands) in human chromosomes // Cytogenet. Cell Genet. 27: 190-193.

Souza A.C.P. 2003. Descrição cariotípica de peixes dos gêneros Baryancistrus, Parancistrus, Peckoltia e Ancistrus (Ancistrinae, Loricariidae) da bacia Amazônica. Belém, PA. Unpublished Mastership Dissertation, Museu Paraense Emílio Goeldi, Universidade Federal do Pará. 130 p.
Sumner A.T. 1972. A simple technique for demonstrating centromeric heterochromatin // Exp. Cell Res. 75: 304-306.

Received December 18, 2009.

Accepted by V.A. Lukhtanov, March 16, 2010.

Published July 09, 2010. 